\title{
NARRATIVAS, REPERTÓRIOS E APRENDIZADO: BORDADOS E BORDADEIRAS
}

\author{
Thaís Fernanda Salves de Brito ${ }^{1}$
}

\begin{abstract}
Um vaqueiro estava perdido no meio de uma mata bem fechada, conhecido como mufumbal. Estava receoso diante do lugar desconhecido, quando se encontrou com um touro bravo no meio daquele sertão. $\mathrm{O}$ boi diante do vaqueiro tornava-se cada vez mais bravo, e de lá, o homem não conseguia fugir. Alguns dizem até que o touro estava tomado pelo espírito de uma divindade e que iria matar o vaqueiro porque ele estava desbravando o lugar que era do touro. Era o touro e o homem. E só.
\end{abstract}

Diante do touro, e do temor que crescia, o homem fez uma oração à Sant'Ana. Sant'Ana é a avó de Jesus, e, também, cuida dos vaqueiros. Na oração, ele roga para que a santa o livre do animal. Como um milagre, de repente, o touro sumiu. No local do ocorrido, o vaqueiro, então, resolve limpar o terreno e edificar uma capela para adoração da avó de Jesus.

Porém, conforme o homem edificava a igrejinha, uma seca muito intensa tomou conta da região. Cada vez mais grave, a seca colocava em perigo a vida dos habitantes do vilarejo e, do mesmo modo, o término da construção da capela. Sabendo que Sant'Anna é poderosa, buscou-a novamente. Foi quando observou que, próximo à capela, havia um poço e vaqueiro, então, rogou para que aquele poço não secasse e mantivesse vivo o povo da região. E o poço não secou.

Ao longo dos anos, assim tem ocorrido, independente de quão grave é a seca: o poço de Sant'Ana nunca seca. Porém, o espírito do touro encantado ainda ameaça, pois ele foi habitar o corpo de uma serpente enorme que poderá destruir a cidade caso o poço venha a secar ou, então, quando as águas do rio Seridó chegarem até o altarmor da Matriz de Caicó.

\section{Introdução}

A lenda do vaqueiro é repetida com frequência em Caicó. Cavignac (1999) se debruçou sobre este mito de fundação da cidade de Caicó que narra uma batalha sobrenatural entre uma santa cristã e espírito indígena, manifesto no touro encantado. Para a antropóloga, a "Lenda do Vaqueiro" - dentre outros mitos e narrativas sobrenaturais potiguares - tem um papel central na elaboração e na reivindicação de identidade regional. A relação complexa entre homem e natureza, colonizador e populações autóctones, território muitas vezes ameaçador percorrer essas narrativas, assim como se apresentam alguns valores considerados positivos e desejáveis: religiosidade, persistência e coragem.

Como uma expressão simbólica, construída e repetida por vários atores que vivenciam uma determinada realidade, esta é uma narrativa coberta de interpretações e

\footnotetext{
${ }^{1}$ Universidade de São Paulo, Brasil.
} 
nela há um tipo de "visão 'popular' do tempo e do espaço" (Cavignac, 1999). É composta por conteúdos imagéticos polarizados que comportam, de um lado, uma representação do espaço 'selvagem' ligado “a autoctonia e, de outro, uma "imagem vitoriosa da colonização da terra" que conseguiu "impor uma apropriação efetiva e simbólica da paisagem habitada" (Cavignac, 1999: 253), alterando a concepção do espaço e construindo uma outra lógica do tempo a partir do modelo do colonizador: o vencedor desta batalha; ainda que temporariamente, afinal, a conclusão do mito permanece em suspenso, porque serpentes e águas violentas sempre são uma ameaça.

A narrativa que abre este artigo, por meio da linguagem mítica, indica um divisor entre o espaço sobrenatural, entendido como ameaçador, e a fronteira com a cidade que "pacifica" as relações, como indica Cavignac. Há uma cena de mudança: o milagre. Mas, há, também, a presença de personagens e imagens que são projetados sobre uma região e que podem nos ajudar a "puxar os fios" desta complexa rede.

Alguns elementos do espaço seridoense são projetados em imagens que descrevem uma geografia específica: uma terra "infértil" que gera constante medo da seca; não por acaso, a história se passa no mufumbal ${ }^{2}$, este é um território hostil. O confronto mítico entre o touro e a santa, por sua vez, traz à tona apropriações efetivas e simbólicas sobre este território estigmatizado pela violência e aridez sertaneja. E mais, as adversidades naturais (a terra seca) podem ser sanadas por meio dos poderes sobrenaturais da santa, que salvam o vaqueiro e toda a região.

É por sua presença que nasce a Freguesia da Senhora Sant'Ana, atual Caicó ${ }^{3}$, “terra de Sant'Ana”, aquela que socorre os seus fiéis e que mantém a união do lugar. Assim, por meio da presença de Sant'Ana, o território perigoso e a ameaça selvagem são apaziguados pela santa redentora, constrói-se, então, a imagem vitoriosa da colonização, impondo "uma apropriação efetiva e simbólica da paisagem habitada" (Cavignac, 1999: 255). Com isso, uma outra história passa a ser escrita. A "terra de Sant'Ana”, é também a terra dos currais de gado e das lavouras de algodão, culturas trazidos pelos portugueses no processo de colonização do espaço seridoense e que

\footnotetext{
${ }^{2}$ Mufumbo é um arbusto comum nas regiões do semiárido brasileiro que se constitui por uma pequena árvore, com copa fechada, repleta de galhos finos e que formam uma mata fechada, sendo utilizada como abrigo pelos animais (Lorenzi, 2002).

${ }^{3}$ O registro da "Povoação de Caicó" data de 1735. Em 1788, é nomeada "Vila Nova do Príncipe"; em 1868, a vila se torna "Cidade do Príncipe" e, posteriormente, em 1890, "Cidade do Seridó". Emancipa-se como cidade em 7 de julho de 1890, já com o nome de Caicó (Macedo, 2000).
} 
estruturou o trabalho, as relações sociais e políticas na região durante toda a sua história (Macêdo, 2000).

A Caicó de Sant'Ana, do gado e do algodão é também a "terra do bordado". Complementarmente ao trabalho com a lavoura e com a pecuária - ofícios tipicamente masculinos-, as mulheres da região bordaram e seguem bordando e, por meio destes bordados, reinterpretam e reinventam narrativas, sejam elas sobre o bordado e as suas bordadeiras, sobre o espaço doméstico (louvando a família pelos cuidados e pelos ornamentos da casa) e sobre a região por meio de perspectivas peculiares.

Assim como as narrativas dos mitos revelam uma expressão simbólica, existem objetos construídos por representações estéticas que permitem vias de acesso para os sistemas simbólicos. A cultura do bordado, tão amplamente difundida em Caicó, aponta para esta possibilidade. Uma vez entendida como sistemas simbólicos, resultado visível de técnicas e de práticas sociais, é possível observar possibilidades de comunicação com padrões e perspectivas mais amplas, e que estão em constante circulação.

Partimos do pressuposto que os bordados oferecem uma narrativa sobre os papeis sociais e sobre a ocupação do território, ao mesmo em tempo que acrescentam novas leituras das terras seridoenses pela estética da ornamentação dos tecidos, no qual emerge uma narrativa que apazigua a terra árida, a geografia difícil, o trabalho árduo, a luta entre o selvagem e o processo de colonização. Ao perscrutar as pegadas de mulheres de Caicó e de seus bordados é possível se aproximar de relações que se tangenciam pela prática artesanal e por seus artefatos que guardam, em si, significados sociais que se projetam nas coisas uma série de atributos, principalmente, no que tange às concepções de gênero (Carvalho, 2008).

Borda-se muito por lá ${ }^{4}$. Bordar é uma atividade que envolve processos de aprendizado, disciplina o corpo, domínio de técnicas e de repertórios, criação de vínculos, construindo uma forma de estar e de ver o mundo. Os bordados apresentam o

\footnotetext{
${ }^{4}$ Naquela região, bordado consiste em uma prática de suma importância para a vida local, envolvendo cerca de $20 \%$ das mulheres que se dedicam a sua produção como trabalho e geração de renda na região (Perfil dos municípios brasileiros, 2005). Destaco que há uma imprecisão destes dados, uma vez que foram fornecidos ao Instituto Brasileiro de Geografia e Estatística (IBGE). a partir de um levantamento que a Associação das Bordadeiras realizou quando oferecia cursos de formação, capacitação e de atualização de bordadeiras entre 2003 e 2006. Desde 2011, tem sido feito o levantamento de artesãos por meio da inscrição voluntária para a obtenção da carteira do artesão, um projeto estatal de políticas para o fomento, formalização e profissionalização do artesão brasileiro. No Rio Grande do Norte, a Secretaria do Trabalho, de Habitação e da Assistência Social (SETHAS) coordenam este levantamento. Até o momento, segundo dados do Serviço Brasileiro de Apoio às Micro e Pequenas Empresas (SEBRAE), parceiro do SETHAS, foram cadastrados 3,5 mil artesãos.
} 
prazer da beleza, revelam um novo olhar frente às imagens de miséria e de confinamento que cercam o imaginário do sertão nordestino. Mais do que uma saída econômica ou uma política específica para o desenvolvimento regional, trata-se de uma experiência estética da comunidade seridoense que mobiliza relações sociais, tangenciadas pela produção artesanal. O bordado é uma narrativa. E como uma narrativa, guarda, em si, outras narrativas que o compõem.

Este artigo é fruto de uma pesquisa ampla, uma etnografia, desenvolvida entre os anos de 2006 e 2010, para minha investigação de doutorado. Intitulada "Bordados e bordadeiras: Um estudo sobre a produção artesanal de bordados em Caicó/RN" interessou-me investigar como o bordado - prática artesanal, doméstica e feminina descortina questões de ordem social, econômica, histórica e cultural de uma região do interior nordestino. Este artigo apresenta um recorte da investigação, é um ensaio que tem como objetivo refletir como a cultura material - o bordado - acessa, por meio da memória, elementos narrativos que tratam da relação das mulheres com o espaço e sua paisagem, apropriando-se e reinterpretando a realidade física a partir de sua experiência estética com a produção artesanal e, também, refletir como esse processo repercute na formação de outras bordadeiras que, inevitavelmente, vão aprendendo a ler e a narrar as histórias e as paisagens através dos tecidos, das linhas e das agulhas.

Para isso, este ensaio está organizado em dois temas somados a esta breve introdução e considerações finais. A primeira parte, intitulada: "Bordados como narrativa da história, da natureza e da geografia de um lugar" apresenta a produção de bordados, inserida em um sistema histórico e econômico, e a elaboração estética de uma leitura feminina sobre e para a região. A segunda parte se propõe a observar o bordado como uma narrativa no corpo; evidenciam-se as narrativas sobre o que é ser bordadeira por meio do ensino do ofício, afinal, não se ensina, apenas, uma técnica ou uma coordenação de cores; ensinar a bordar é ensinar a ser uma bordadeira, o corpo precisa se tornar apto, ao mesmo tempo, em que se aprende a modelar sensibilidades e concepções sobre o que é ser uma mulher naquela região.

\section{Bordados como narrativa da história, da natureza e da geografia de um lugar}

A sertaneja Caicó localiza-se em plena zona da caatinga do nordeste do Brasil. É frequentemente descrita, tanto pelos órgãos oficiais, quanto pela literatura e artigos, 
produzidos por estudiosos da cidade, em função do meio físico (o semi-árido), do ciclo da natureza e da carência nos mais variados níveis.

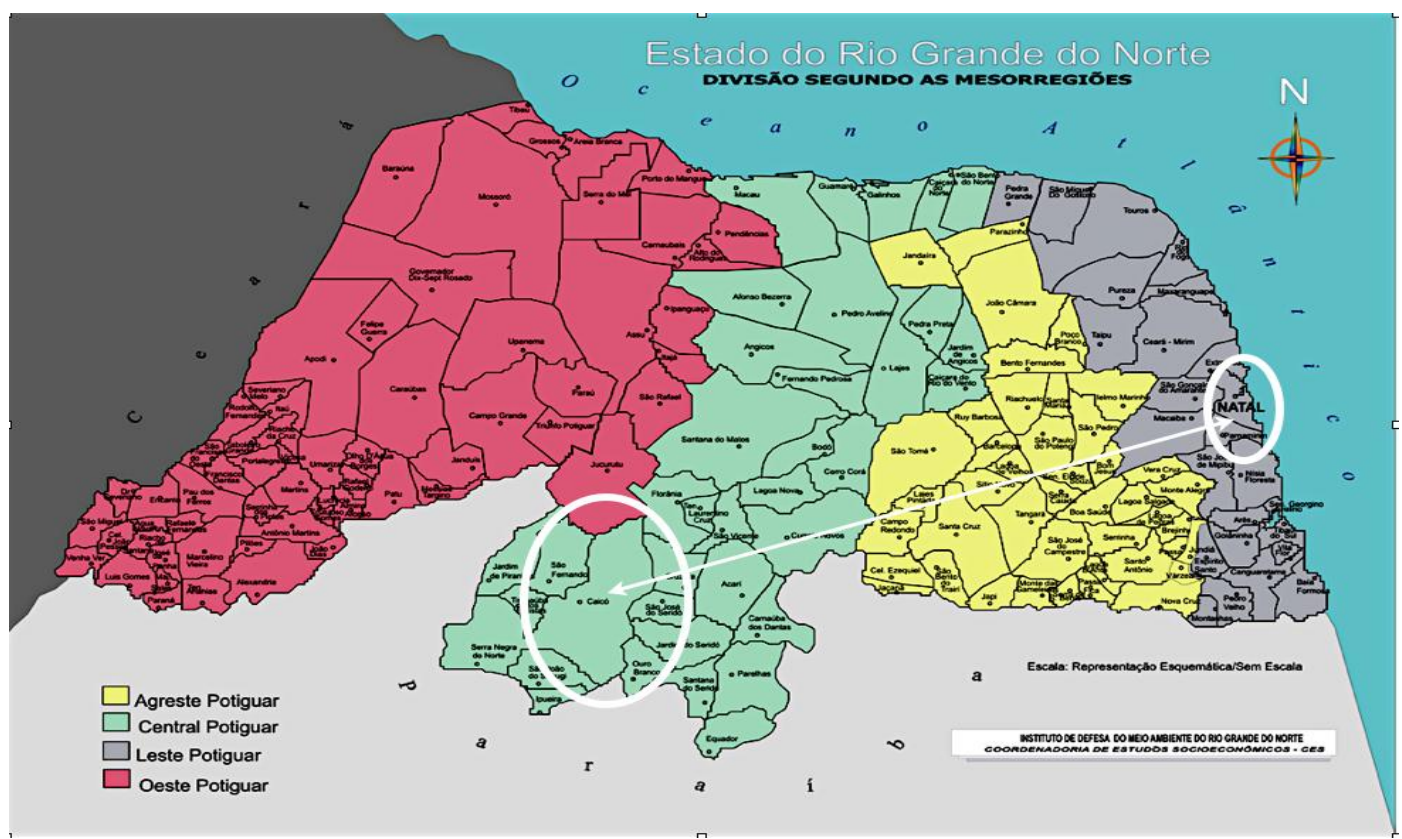

Figura 1- Mapa político do Estado do Rio Grande do Norte, com divisão segundo as Mesorregiões. Destaque, pela autora, das cidades de Natal e Caicó. Fonte: Elaborado pelo Instituto de Defesa do Meio Ambiente do Rio Grande do Norte (IDEMA).

A cidade de Caicó é parte da região do Seridó, fixado em pleno sertão do Estado do Rio Grande do Norte. Em 2013, registrou-se uma população de 62.709 pessoas, habitando uma área de 1.228,57 $\mathrm{Km}^{2}$. A capital do Estado é Natal que se solidificou como um destino turístico importante para o Brasil. Caicó fica a $263 \mathrm{~km}$ de Natal. Somada às percepções sobre o clima, é possível ver que essa é uma área sujeita não apenas às estiagens prolongadas, mas a ideias, imagens e sentimentos que criam, simultaneamente, enredos e discursos em torno da carência e da sobrevivência.

A região do Seridó (figura 2) encontra-se delimitada a partir da bacia hidrográfica Piranhas-Açu, que tem o rio Seridó como um de seus afluentes. Essa bacia nasce no Estado da Paraíba, percorre cerca de 240 km e se encerra na Barragem do Boqueirão, na cidade de Parelhas/RN (Morais, 2005). 


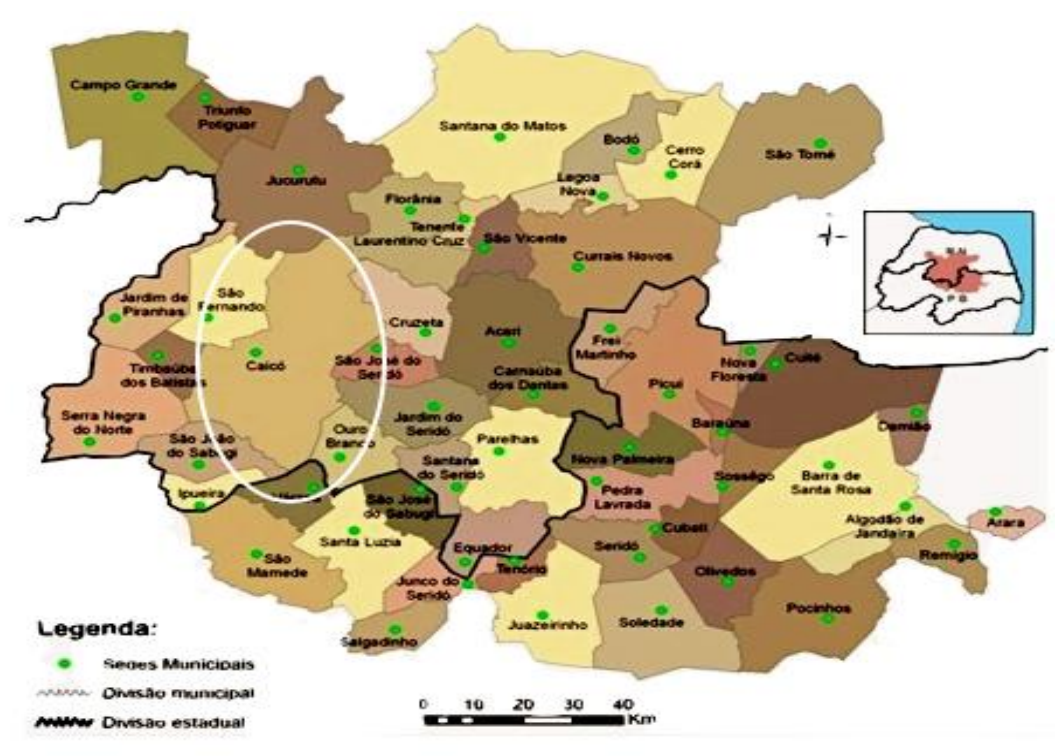

Figura 2 - Mapa da região do Seridó. No detalhe, vê-se o Seridó a partir da divisão política dos estados da Paraíba e do Rio Grande do Norte, com destaque, pela autora, da cidade de Caicó. Fonte: Agência para o desenvolvimento do Seridó (ADESE).

A geógrafa Ione Morais (2005) assim descreve o Seridó:

... Mudando seu perfil de acordo com a sazonalidade, a caatinga exibe duas paisagens bem diferenciadas. No período chuvoso, suas plantas recobrem-se de folhagens e se mostram exuberantes o suficiente para, em um verdadeiro emaranhado, produzirem um cenário em que a tonalidade do verde assume diversas gradações. No período da seca, as plantas perdem as folhas deixando à mostra seus galhos retorcidos e seus troncos espessamente cobertos. O tapete verde cede lugar a uma paisagem acinzentada que assume um certo ar de agressividade, expresso através das plantas aparentemente mortas com salientes espinhos a desafiar o tempo e o espaço adverso. (MORAIS, 2005: 24)

A autora descreve a região a partir de algumas características da caatinga. Seu foco está colocado nas duas estações climáticas - seca e chuvosa - que estão na base de um repertório de imagens correntes projetadas para a região. A lógica explicativa alimentada pelo clima mostra que: se há água, há exuberância e um cenário com diversas gradações de cores; mas, na falta d'água, a paisagem fica retorcida, agressiva, paradoxalmente morta e desafiadora.

$\mathrm{Na}$ análise sociológica da região, a seca e a falta de água emergem como personagens centrais para as possibilidades de sobrevivência, como também para a sociabilidade. Um exemplo disso são as palavras de José Augusto de Medeiros, cujas ideias repercutem nas imagens construídas sobre o local e que ainda hoje influenciam, 
em especial, as políticas públicas estatais. Medeiros interessava-se pelos temas que cercam a relação homem-espaço na região, descrevendo' este território sertanejo como:

Região descalvada, montanhosa, eriçada de pedregulhos e espinhos, sujeita ao flagelo contínuo das secas, convida o homem para o labor contínuo, para a luta áspera com os elementos da natureza e não lhe permite lazeres para a contemplação das coisas belas, de resto muito raras naquelas paisagens (Medeiros apud Macedo, 2005: 72). Grifos meus.

A descrição acima se configura a partir de uma representação frequente sobre o ambiente sertanejo: de sobrevivência difícil, agressiva e cuja viabilidade econômica tende à infertilidade. Um lugar "descalvado" e "seco"; para sobreviver nele (e a ele), restava apenas o "labor contínuo", manifesto em "luta áspera" contra uma natureza considerada inóspita. Por isso, não há lazer, não há contemplação. Para Medeiros, inclusive, a beleza era algo pouco importante porque a falta d'água havia tornado raras as coisas belas da região.

Sem querer negar o valor de tais interpretações para a compreensão de aspectos relevantes, não foi a descrição das adversidades e carências que me levaram ao sertão. Conheci Caicó por meio da contemplação de suas coisas delicadas e belas. Foi o bordado - sua riqueza e exuberância - que me levou à cidade. Os bordados produzidos, fonte de trabalho e lazer para muitas mulheres, apresentaram-me ângulos novos de percepção do lugar. A interpretação da paisagem pelos bordados indica uma leitura diversa sobre a experiência das pessoas: trata-se de outro ponto de vista sobre o espaço seridoense e seus habitantes, especialmente sobre o universo feminino.

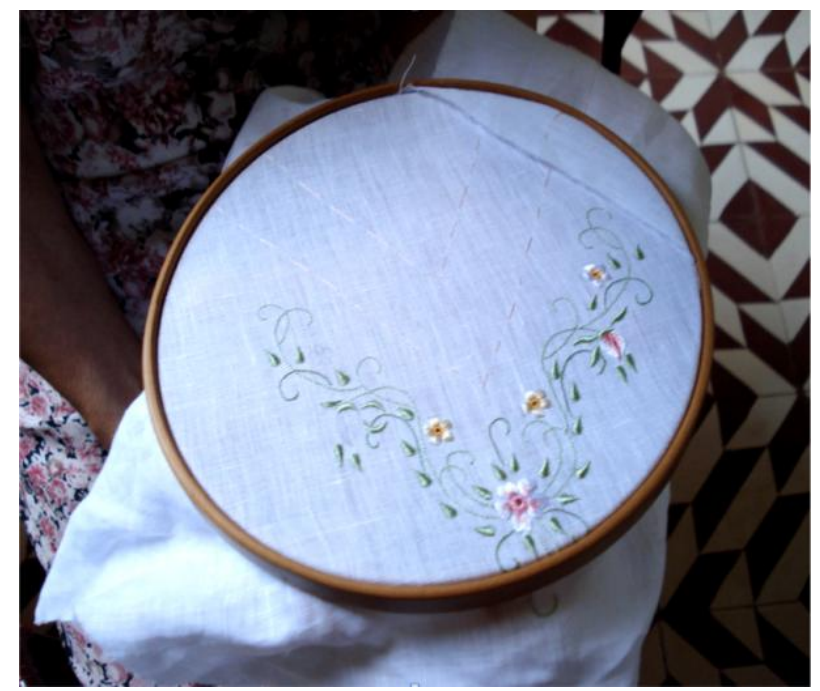

Figura 3 - Uso do bastidor para o bordado à mão, peça de Rosalba, 2007. Foto: Thaís Brito. 
Os bordados permitem, portanto, outra perspectiva de apreensão e compreensão da cidade, na medida em que nos endereçam também à natureza, ao invés das imagens da pobreza do ecossistema. O espaço está lá, mas a interpretação da paisagem fala de uma experiência social. A natureza que está presente nos bordados é composta de flores e folhas, surgindo, algumas vezes, elementos figurativos como pássaros e insetos. Noutras vezes, os bordados apresentam uma natureza estilizada por meio dos arabescos. De todo o modo mantém afastado qualquer sentido de rudeza ou de infertilidade, conforme verificamos no bordado a seguir.

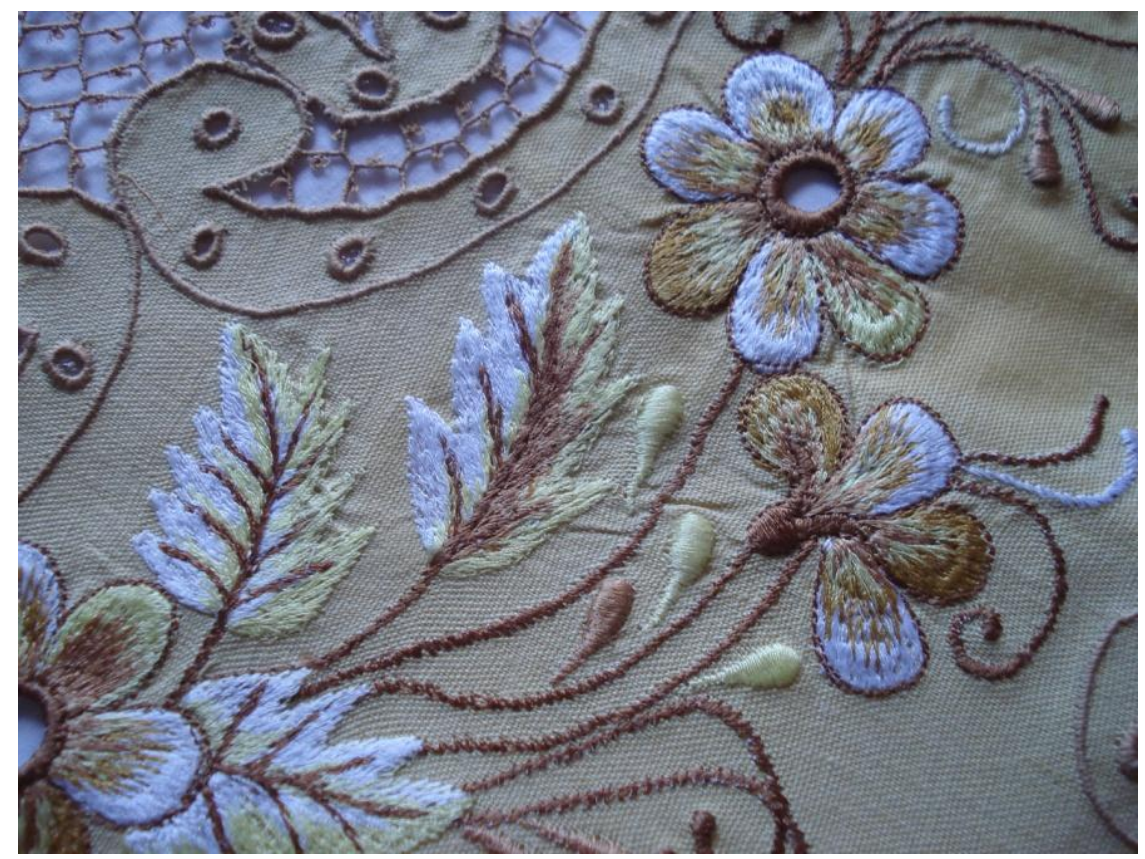

Figura 4 - Toalha de linho bordada em richelieu e matizado por Iracema Batista, 2006. Foto: Thaís Brito

A presença de elementos estilizados da natureza, nos bordados, é uma característica recorrente de grande parte deles, em geral; no caso em questão, tais representações subvertem uma geografia da aridez. Mas não somente. Esses bordados fornecem outra leitura da história da região, valorizando a herança das primeiras colonizadoras portuguesas, no espaço seridoense.

Macedo (1998) mostra que "o espaço seridoense foi construído a partir da expansão pecuarística no âmbito da economia colonial” (Macedo, 1998: 613). As portas do sertão foram abertas para a criação do gado que, além da carne e do couro, forneceu a força motriz para as lavouras de cana, permitindo que seus engenhos tomassem todo o 
litoral nordestino, uma vez que o açúcar era "o produto agrícola de exportação mais rentável para a lógica econômica do Antigo Sistema Colonial” (Macedo, 1998: 612). Os homens do Seridó moldaram o sertão a partir das práticas pastoris.

O projeto de colonização da região tornou-se conhecido como o "ciclo do gado" . Era preciso acostumar o gado, amansá-lo, adaptar os campos, extinguir os predadores, abrir cacimbas, vencer a fome, descobrir o sal, conhecer o ciclo dos rios, entender o inverno, expulsar as populações autóctones, impor outra lógica de gerenciamento dos recursos naturais, enfim, uma prática econômica que eliminou áreas agriculturáveis - e, por extensão, seus ocupantes tradicionais - em favor dos grandes currais de gado.

No "Seridó Antigo", a vida se organizava em função do gado (bovino e caprino) e dele se retirava tudo o que fosse necessário à sobrevivência: carne e leite (e todos os seus derivados), couro (que servia para auxiliar a lida no campo e a composição dos móveis e acessórios da casa), os ossos e o esterco ${ }^{6}$. Observa-se, assim, que o gado forneceu (e fornece) muito mais do que alimentação, fomentando, inclusive, formas estéticas, prioritariamente masculinas, no trato com o couro.

O couro servia para auxiliar a lida no campo e era usado na composição dos móveis das casas. Estava nos bancos e nas camas; na roupa do vaqueiro, na selaria, nas bolsas de viagem (matulão), nos sapatos e sandálias. No trato com o gado, o couro era o material utilizado no fabrico de cordas de contenção e para ajudar no trabalho com os animais ${ }^{7}$.

Amaciar o couro é um processo artesanal ${ }^{8}$. Tal qual o boi, um animal forte e violento que precisa ser domesticado para ter vida útil ao trabalho, o couro pede domesticação. Para obtê-lo, é preciso, antes de tudo, da morte. Depois de retirada toda a carne, o couro precisa ser limpo, sacando-se dele qualquer sinal de vida, como, por

\footnotetext{
${ }^{5}$ O ciclo do gado foi estudado por Medeiros (1980), Macedo (1988 e 2004), Dantas (2004) e Morais (2005), priorizando a perspectiva histórica. Esses autores assinalam que o período se estende de 1831 quando houve o decreto da criação de Vila Nova do Príncipe, como província do Rio Grande do Norte, até o final do século XIX, com a produção de algodão.

${ }^{6}$ Do esterco, tira-se o adubo e, nos tempos mais antigos, servia para compor a mistura para a construção e reboco de paredes. O chifre se torna berrante e pode ser usado, ainda, para guardar pequenas coisas, além de servir como objeto de decoração. Os ossos também são aproveitados, principalmente para fazer mocotó e, uma vez triturados, podem servir de adubo.

${ }^{7}$ Capistrano de Abreu observa: "De couro era a porta das cabanas, o rude leito aplicado ao chão duro, e mais tarde a cama para os partos; de couro todas as cordas, a borracha para carregar água, o mocó ou alforge para a comida, a maca para guardar roupa. A mochila para milhar cavala, a peia para prendê-lo em viagem, as bainhas da faca, as broacas e surrões, a roupa de entrar no mato, os banguês para cortume ou para apurar sal; para os açudes, o material do aterro era levado em couros puxados por juntas de bois que calcavam a terra com seu peso; em couro pisava-se tabaco para o nariz." (Capistrano de Abreu, 1930: 72) ${ }^{8}$ Agradeço a Mauro Tadêo de Brito - meu pai, outrora um homem que trabalhava com o gado - pela descrição paciente do processo de curtição do couro.
} 
exemplo, os pelos, o cheiro do sangue e da carne. O cheiro é muito desagradável. É preciso secá-lo, sendo necessários vários dias, intercalando as exposições ao sol e à sombra.

O couro, depois desta primeira preparação, ainda duro, precisa ser amaciado, curtido, dobrado e curado. A maciez do couro é produzida pelo homem, em uma tarefa árdua que demanda força, tempo e paciência. Trata-se de um exercício de dominação. E apesar da prática civilizatória da produção material do couro, ele ainda permanece rústico e, de certo modo, indomável. Uma vez macio, os homens costumam adorná-lo alguns, ainda o hoje o fazem - com desenhos, tachas e costuras, criando uma estética peculiar, como a da sela do vaqueiro usada na procissão de Sant'Ana, em 2008:

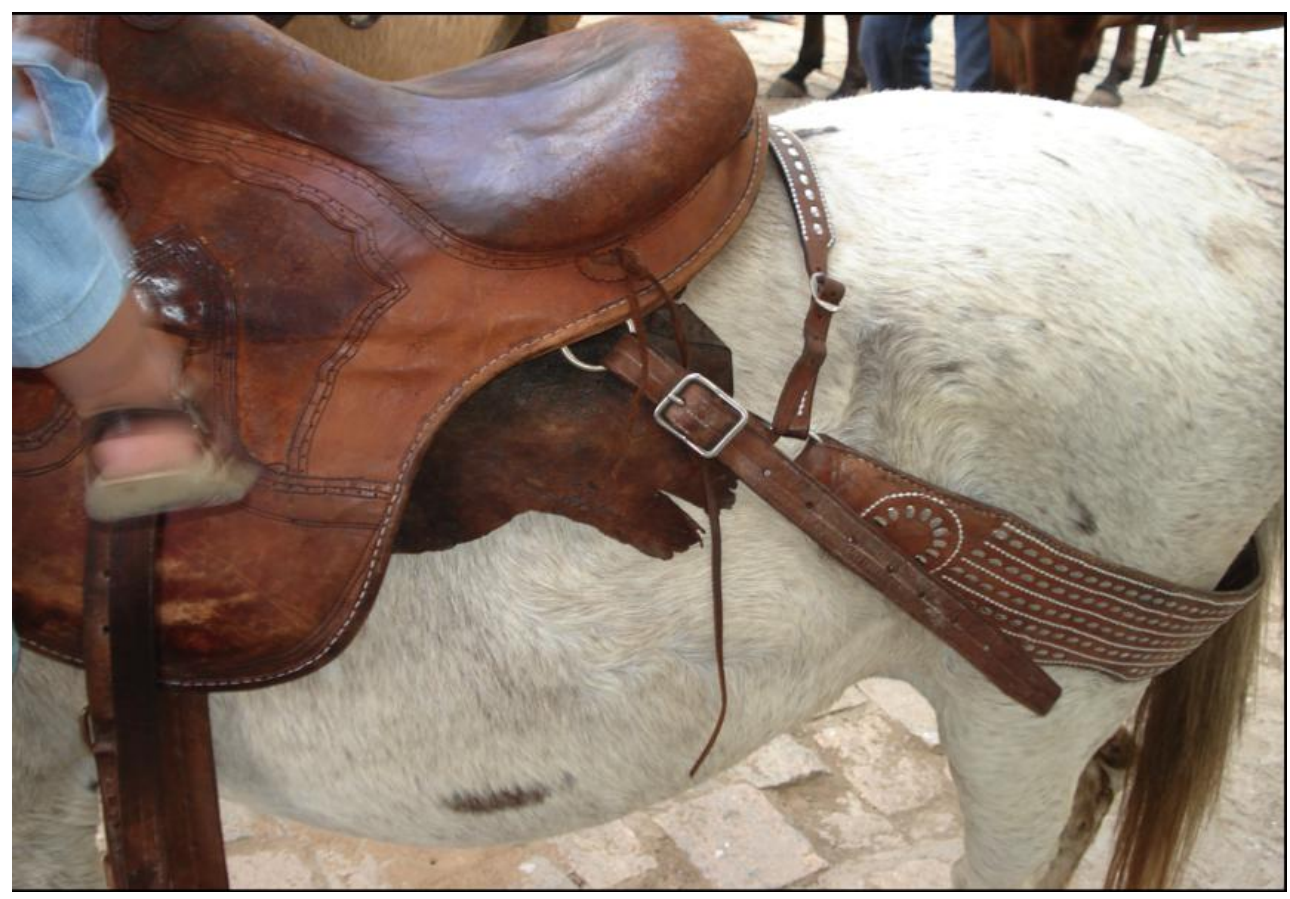

Figura 6 - Sela do Vaqueiro. Festa de Sant'Ana, 2008. Foto: Thaís Brito

Fixar-se no Seridó significou também construir cidades (Macêdo, 2005). A organização do espaço urbano em Caicó remete à fundação da cidade em 1687, quando foi construída a casa "Forte do Cuó", dando origem ao povoamento do espaço. Em 1735, ampliou-se o número de habitantes com o estabelecimento da fazenda Penedo, atualmente, bairro Penedo. Na época, a cidade era chamada Vila Nova do Príncipe. Em 1748, foram lançadas as bases para a construção da Capela de Sant'Ana, originando a Freguesia de Sant'Ana. Em 1788, Caicó torna-se cidade. 
A cidade de Caicó nasceu a partir das fazendas de gado. Os currais compunham "embriões de estruturas de fazenda que viriam a se tornar marcantes no cenário da organização socioespacial seridoense" e esta ocupação tinha, segundo a autora, um "duplo sentido: povoar o sertão com gentes e gados, erigir casas e currais" (Morais, 2005: 63). A lógica era ocupar os espaços tidos como devolutos com extensas áreas de pastagens e grandes currais, com a decisão de explorar o rebanho propriamente dito a fim de fornecer carne e derivados para o consumo nas cidades coloniais no litoral (Medeiros Filho, 2001).

Na segunda metade do século XIX, a cotonicultura aparece como uma atividade complementar à pecuária, agregando o branco do algodão, de tipo mocó, à paisagem caicoense $^{9}$ (Dantas, 2005; Morais, 2005; Macêdo, 2004). A cotonicultura, mais do que uma cultura adaptada ao solo e ao cotidiano dos habitantes da região, teve a importância de inserir o Seridó nas dimensões políticas do Nordeste, uma vez que possibilitou que a região se inserisse no mercado agrícola nacional e internacional, alterando, no século XIX, o eixo político potiguar que migrou do litoral para o interior (Morais, 2005). Ademais, incluiu o trabalho feminino na lavoura - mesmo com intensidade distinta da realizada pelo trabalho masculino - e introduziu algumas perspectivas de gênero na descrição do próprio trabalho, principalmente no de fiar e nas artes da agulha, minuciosas ações femininas no Seridó, presentes antes mesmo da chegada do colonizador (Câmara Cascudo, 2003).

Gado e algodão formaram um importante binômio produtivo no Seridó. Esses ciclos econômicos caracterizaram a produção econômica da cidade até as décadas de 1960 e 1970 (Macêdo, 2004-2005), definindo tanto a produção econômica quanto as relações de trabalho e suas representações sociais (Morais, 2005). É possível que a inserção do algodão no local tenha impactado inclusive alguns discursos sobre o comportamento das pessoas da região. Morais (2005) observa que os seridoenses associam o tipo de algodão aos aspectos naturais da região:

\footnotetext{
${ }^{9}$ O algodão de tipo mocó é reconhecido pela qualidade da "fibra, sedosidade, coloração e resistência" (Morais, 2005: 161). Na segunda metade do século XIX, houve uma expansão da cultura do algodão em grandes lavouras brasileiras visando à exportação, nos estados de São Paulo, Minas Gerais, Paraná, Paraíba, Ceará e Rio Grande do Norte. Esse modelo produtivo foi amplamente incentivado no início da República (SENAI, 2009).
} 
A associação entre o tipo de algodão e a região em que melhor adaptou-se repercutiu em termos de designação, passando a malvácea a ser nominada de mocó ou seridó. Dentre as múltiplas leituras que este fato pode suscitar, uma delas alude à associação imagética entre os seridoenses, homem de fibra, tão resistente quanto o algodão de fibra longa que produziu. (Morais, 2005: 161)

Foi o algodão, do tipo mocó ou seridó, principalmente na segunda metade do século $\mathrm{XX}$, que constituiu um marco na economia potiguar (uma vez que o seu cultivo, beneficiamento e comercialização abriram possibilidades para uma produção que dinamizou a exportação do produto). Contudo, mais do que uma nova inserção econômica, o ciclo do algodão articulou o campo à cidade, funcionando como alavanca para o desenvolvimento regional e projetando, tanto a região quanto sua cidade mais importante, Caicó, de modo a obter alcance regional (Morais, 2005).

$\mathrm{O}$ algodão projetaria o Seridó, nos primeiros anos do século XX, para um Brasil da indústria moderna. Com a cotonicultura, a vida na cidade de Caicó se deslocou do campo para a cidade, em função do beneficiamento do algodão, conduzindo à priorização da urbanização, à necessidade de escolas de formação básica e profissional, ao estímulo do comércio e ao desenvolvimento de estradas para escoar a produção. Com o algodão, o Seridó estaria, portanto, apto aos novos tempos, à industrialização e à ruptura com o isolamento. Tal movimento seria completo se houvesse açudes e estradas, quando, por meio do Departamento Nacional de Obras de Combate às Secas - DNOCS -, foram desenvolvidos projetos de infraestrutura viária e de irrigação para a região. As possibilidades que viriam com a cotonicultura eram tão importantes que a bandeira da cidade de Caicó que, não por acaso, tem, no centro, o algodão:

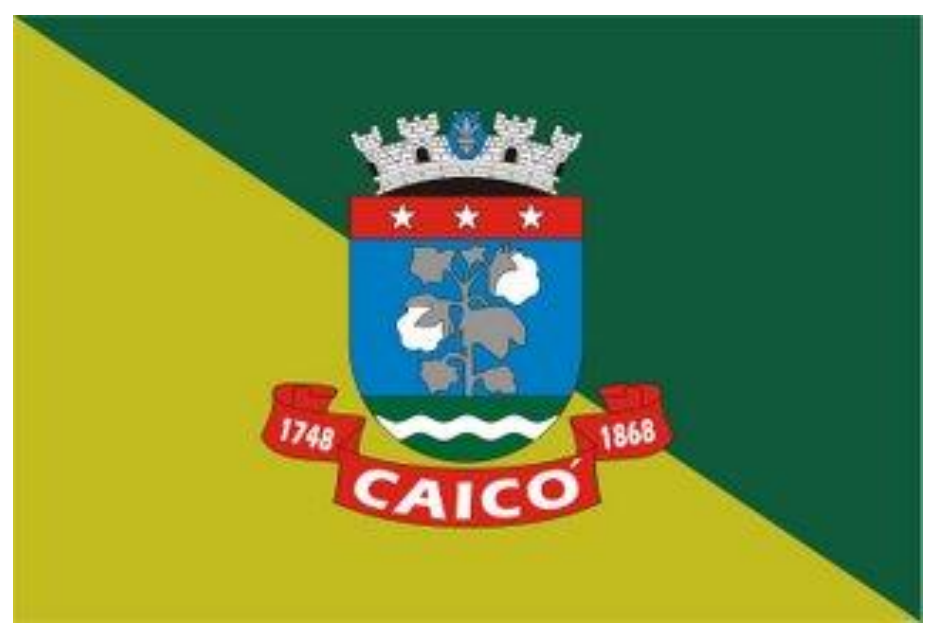

Figura 7 - Bandeira da Cidade de Caicó. Fonte: Prefeitura de Caicó 
A dinâmica da produção algodoeira trouxe, para a região, o status de fornecedor de matéria-prima para a indústria da tecelagem, entre o final dos anos de 1860 e a década de 1930, como indica Morais (2005). Apesar da produção não ser muito grande, se comparada à paulista, o algodão era de boa qualidade e tinha um beneficiamento considerado satisfatório para a industria. Este foi um período de abundância para a cidade, proporcionado pelo cultivo do algodão.

A cotonicultura, realizada em lavouras maiores com a finalidade de exportação, tinha, como maior grupo de trabalhadores, os homens. Mas, na produção menor, algo frequente ocorria em Caicó: as mulheres eram a maioria na colheita do algodão, obviamente que eram as mulheres pobres. Se comparada ao trabalho com o gado, a cotonicultura, do ponto de vista da rotina do trabalho, apresentou características mais próximas do modelo feminino.

A colheita é uma tarefa cuidadosa, sendo preciso manter a atenção para evitar que, junto com a fibra (capulhos), venham impurezas e materiais estranhos. Por esta razão, é preciso colher rapidamente com ambas as mãos, sem machucá-los, cuidando para não colher os capulhos doentes, com pragas ou até mesmo os que estão molhados pelo orvalho. O capulho é como uma cápsula, um invólucro que abriga a flor do algodão.

Assim como o couro, o algodão também é fruto da natureza, mas lidar com flores é completamente distinto do que lidar com o gado. É interessante notar como a prática de trabalho com o gado e com o algodão aponta para convenções de gênero. O trabalho das mulheres está presente no cultivo, na colheita, no beneficiamento e na fiação do algodão; além disso, se o trato com o couro exige rusticidade, o algodão, por sua vez, pede "delicadeza" - qualidade que fundamenta e acompanha também o ensino e a prática do bordado. As fibras do algodão são obtidas diretamente da natureza e sua preparação, o filamento, é realizado por meio de processos mecânicos que podem ser artesanais ou industrializados. Apesar da colheita não ser fácil (sol quente, espinhos, trabalho árduo) não traz em si perspectiva de dominação pela força contra a natureza resistente, como no caso do gado e no tratamento do couro (que envolvem o sacrifício do animal).

A tecelagem foi uma indústria doméstica, feminina e tradicional. Essa tarefa se tornou ainda mais rebuscada, continua Cascudo (2003), quando as portuguesas trouxeram consigo teares e novas técnicas que serviram à produção das redes, durante o processo de colonização. Fazer rede tornou-se tarefa feminina. As mulheres de Caicó 
passaram a ordenar o seu cotidiano em função da produção das redes. "A vida era assim", disse Ítalo, um dos raros bordadores da região ${ }^{10}$, relembrando o passado no campo: "a roça com o algodão, a casa e mais nada e quando não era o plantio, fazia-se rede".

A importância da rede remete à necessidade do algodão como matéria-prima e à tecnologia do tear, que precisa ter qualidade para dar conta de suas múltiplas funções. Além disso, a rede é muito versátil e sua presença é constante no cotidiano. Assim como os bordados, as redes estão nas casas, são dependentes do algodão e pedem técnicas (tecnologias) específicas, conduzidas pelas mulheres.

Cuidado, limpeza e atenção. O bom trabalho da colheita é obtido a partir da observância destes três elementos, da mesma forma como devem ser feitos a rede e os bordados. Algo interessante a notar é como tais noções estão permeadas nas representações sobre as mulheres de Caicó, isto é, como aptidão naturalizada do seu comportamento e valorização dos atributos de gênero feminino - visto que o papel de "zeladora cuidadosa da casa" aparece nos discursos atuais como uma característica igualmente louvável para a colheita, para a feitura das redes e elaboração dos bordados.

As fibras do tecido, principalmente o linho e o algodão, formam a base material para a produção das peças a serem bordadas. De acordo com os modelos da região do Seridó, o bordado fala de detalhes, enquanto o tecido fala de uma apropriação específica da natureza. A atividade de bordar é prioritariamente feminina e executável na esfera doméstica. Os trabalhos de agulha, presentes em enxovais e roupas, foram (e ainda o são) realizados no âmbito de espaços tradicionalmente femininos, como a casa ou o atelier de costura. Entretanto, as fibras que compõem os tecidos falam de uma vida no campo e contam sobre a difícil vida na fazenda dos primeiros colonizadores, da restrição das mulheres à vida pública, do trabalho feminino na lavoura e nos lares. Testemunham, ainda, empreendimentos políticos no sertão, narram técnicas de trabalho e apontam para as noções de aproximação feminina com a natureza.

Apesar do ciclo do algodão ter sido economicamente representativo quanto à projeção da cidade para circuitos mais distantes, tendo sido também importante para a formação de outras imagens da região, ele teve duração limitada. A produção começou

\footnotetext{
${ }^{10}$ Ítalo viu todas as mulheres de sua família tecer redes e aprendeu desde muito pequeno a técnica. Foi pela fiação e comercialização das redes que ele se inseriu no mundo do bordado. Ítalo foi o único rapaz entrevistado para esta pesquisa, o que revela a restrição a pratica masculina do bordar na região. Muitas mulheres foram parte desta experiência etnográfica, para ter acesso às personagens desta investigação, ver Brito: 2011.
} 
a diminuir nos anos de 1920. Um dos motivos principais é que o estado de São Paulo estruturou uma produção regular e, salienta Morais, “em 1936, era responsável por 50\% da produção algodoeira no país" (2005: 164). Ainda que menor, segundo a autora, o período de 1940-1970 para Caicó foi um tempo promissor, de dinamismo econômico e de projeção política, tudo isso, graças ao algodão. Porém, na década de 1970, a seca voltou a assombrar o Seridó. Para além do ambiente competitivo desfavorável, a questão climática volta à tona como um problema a ser enfrentado pela região durante a década de 1970, o que dizimou o gado e arruinou a produção de algodão.

Diante dessas dificuldades, era necessário criar alternativas para geração de trabalho e de renda. E, o bordado que, até então, era uma prenda doméstica, tornou-se fonte de trabalho e de recursos. Assim, de um meio para ocupar o tempo, disciplinar o corpo, preparar-se para o casamento e para o cuidado com a família, os bordados transformaram-se em alternativa ao trabalho rural. É provável que a primeira mulher de Caicó a se utilizar do bordado de forma comercial tenha sido a modista Maria do Vale Monteiro, que fez das peças ornamentadas mercadorias e fonte de rendimentos.

As mulheres e filhas de fazendeiros preparavam-se para o casamento pelo aprendizado das prendas domésticas, entre as quais o bordado ocupa lugar de destaque. As mulheres pobres, que trabalhavam no campo, buscavam na costura, na feitura das rendas e nos bordados, possibilidades de geração de renda e, portanto, meio de sobrevivência (Falci, 2000). A cultura do bordado foi se criando na região do Seridó por meio das mulheres, independente da classe social ou da função das peças que produziam. As roupas, enxovais e adereços passaram a permear o cotidiano e ir além dele, revelando-se uma possibilidade de transcender a realidade e as possíveis limitações de ordem econômica, social, ecológica ou geográfica. Alguns olhares para a presença do bordado pode conduzir à trajetória dessa cultura.

As mulheres chegaram à região apenas em meados do século XVIII. A inserção feminina na região sertaneja foi também uma resposta à baixa taxa populacional no reino português que precisava de mulheres, de origem europeia, para viabilizar o processo de ocupação do território sertanejo; por meio de uma prole legítima, satisfazendo, simultaneamente, a moral jesuítica e a defesa dos preceitos católicos (Gomes, 2004). Deste modo, as mulheres consolidaram os dois objetivos de ocupação inicial do lugar: proteger o espaço e criar uma sociedade moralizada, por meio da família. 
Aos homens do sertão cabia a lida cotidiana, enquanto as mulheres estavam na lavoura. É possível que algumas das campesinas já soubessem tecer e bordar, como apontou Câmara Cascudo. O treino para esses papéis começava desde a infância, a partir da observação e restrição da conduta. Em torno dos 12 anos, essa ação era reforçada por ocasião do início da confecção dos enxovais. Pela ênfase na confecção dos enxovais como forma de preparação para o papel a ser desempenhado, no lar, é possível observar como a "cultura do bordado" faz parte da criação do cotidiano por meio da gestão da casa.

O foco da vida das mulheres dessa elite mantinha-se nos afazeres domésticos, principalmente a costura e o bordado. Gomes (2004) volta às palavras de D. Francisco Manoel de Melo para lembrar que "às mulheres deveriam ser acessíveis as primeiras letras, sendo que o melhor livro era a almofada e o bastidor" (Gomes, 2004: 14). JeanYves Durand observa que do século XIX até pelo menos a primeira metade do século $\mathrm{XX}$, a bordadeira e a costureira encarnavam a representação da mulher virtuosa:

(...) a bordadeira é a representação por excelência da rapariga virtusa. Quando se quer dar a imagem de uma vida familiar harmoniosa, a figura preferida é a mulher cosendo. É a habilidade como costureira, conjugada com as suas virtudes de poupança e o seu engenho (...) um dos instrumentos da boa aparência, da dignidade, da expressão de uma forma de respeito pela ordem estabelecida (...) A agulha aparece neste conxtexto como o instrumento por excelência de afirmação de uma suposta "natureza feminina". Passando por um estrita disciplina do corpo e da atenção necessária para a boa realização de pontos minúsculos, de motivos regulares, a costureira instalava também as mulheres no seu papel social e restringiaas a ele. (Durand, 2006: 8)

A produção artesanal foi companheira das mulheres na disciplina e na ocupação do tempo, no período de colonização. Mais do que isso, bordar e coser demonstrava um indicativo de riqueza, de prosperidade e da posição social das famílias que prosperavam. Quanto mais sofisticados fossem os enxovais, mais distinta era a família; quanto mais detalhado o enfeite, mais preciosa era a dona da casa e, por consequência, a própria família. Poder dedicar-se, com esmero, às prendas domésticas significava que essas mulheres gozavam de tempo livre para se empenhar em tarefas que não eram de sobrevivência - algo raro em um ambiente que necessita de trabalho intenso.

A utilização dos bordados como ornamentação da casa - e também como forma de distinção social - é analisada por Carvalho (2008), ao estudar as casas paulistas do século XIX e XX. Apesar da distância no tempo e no espaço, a reflexão da historiadora é fértil para a análise sobre o papel do bordado no Seridó, principalmente no que se 
refere à presença da natureza no interior das casas, por meio das mãos femininas. Carvalho (2008) assinala que um dos objetivos do artesanato era marcar a distância de trabalhos braçais, considerados degradantes:

\begin{abstract}
No Brasil, o caráter amador e não produtivo do artesanato doméstico mantém-se não tanto pelo seu poder disciplinador, mas como forma de marcar a distância da dona de casa dos trabalhos braçais sujos, pesados e repetitivos considerados como atividades degradantes. Para ser eficaz, portanto, o artesanato doméstico tinha que mostrar afinidade com a arte, com isso provando ser uma prática criativa e não repetitiva. (Carvalho, 2008: 76).
\end{abstract}

No "Seridó Antigo", a inserção das mulheres de uma elite na região, durante o processo de colonização, acabou por difundir uma arte para aquele território. Os trabalhos artesanais realizados no âmbito doméstico, como a costura, e principalmente o bordado, estiveram aptos para experimentação estética, provocando um comportamento criativo na concepção e na feitura das peças na e para a casa. Também chamadas de "toque feminino", as artes manuais estavam (e ainda estão) difusas pela casa, cobrindo o lar com ornamentos, transformando os objetos, camuflando ambientes ou destacando o valor de algumas peças (Carvalho, 2008).

O possível início da prática do bordado na região do Seridó deu-se em meio ao movimento de colonização do espaço que se compunha por grupos sociais. De um lado, os vaqueiros, ligados à criação dos currais, ao trabalho árduo no campo, à lida com o gado e à tentativa de se formar uma lavoura (muitas vezes, com a ajuda das mulheres camponesas); por outro lado, a presença de uma elite que precisava adequar a vida sertaneja aos modelos civilizatórios do Reino. Apesar de dificuldades distintas, é possível imaginar que ambos compartilhavam a ideia de que a mulher era capaz de suavizar o processo de colonização.

A análise de Carvalho (2008) para as casas paulistas, no início da industrialização, pode iluminar a concepção de uma "natureza feminina" como um filtro para as adversidades externas ao lar, que se fazem presentes nas casas por intermédio dos bordados. As casas paulistas buscavam criar um imagem de conforto, status e disciplina por meio da decoração, do uso dos objetos e da feitura do artesanato pela dona da casa, dentre eles, os bordados (Carvalho, 2008).

É possível que o mesmo processo de busca pelo conforto tenha ocorrido em Caicó, desde a época em que a vida estava centrada na criação de gado e na lavoura de algodão. A ornamentação do lar pôde criar uma imagem distinta do mote da aridez e da 
rusticidade do espaço público, estigmatizado pela violência e dificuldade comuns aos currais seridoenses. Portanto, a delicadeza dos bordados no ambiente doméstico torna a caatinga menos assustadora, suavizando o domínio da vida cotidiana.

Ainda hoje, o que se vê é que os bordados nas casas têm a função de decorar o ambiente e, assim, de torná-la mais bela suave. Vejamos, por exemplo, a leitura de uma vivência específica da natureza, segundo o estilo dos bordados de Caicó, que projeta leitura distinta da natureza árida e inóspita. Nos bordados, ela surge reinterpretada: flores, folhas, pássaros, geometria, cores e sombras, em formas delicadas.

No bordado, a seguir, vê-se um exemplo da interpretação da natureza. O galinho do norte, presente no universo sertanejo, também se revela por meio de uma interpretação peculiar da caatinga:

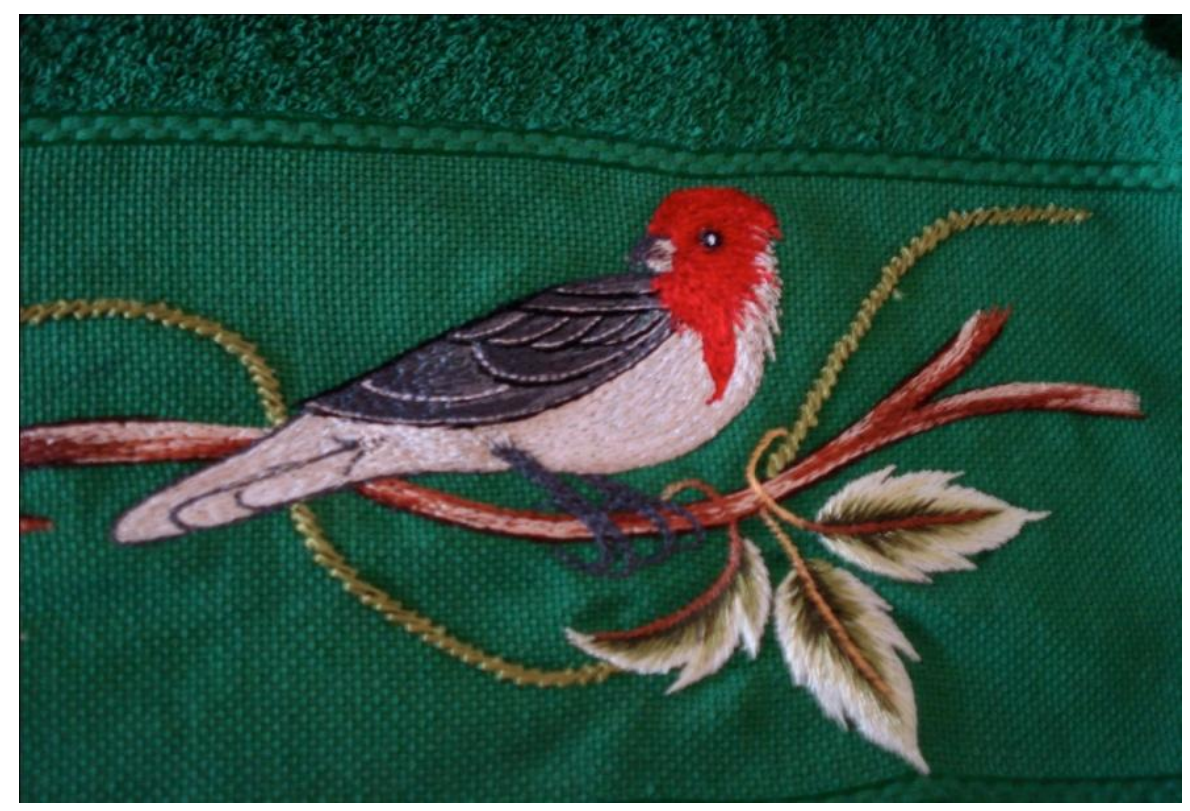

Figura 9 - Pássaro bordado sobre um galho, com ramo de flores, produzido por Lucineide, 2009. Foto: Thaís Brito

A foto destaca o pássaro bordado sobre um galho, com um ramo de folhas. Aqui, a fertilidade se torna ainda mais explícita, pela presença das folhas, pelo vermelho vivo de suas penas. Foi produzido por Lucineide para a sua participação na Feira de Artesanato dos Municípios do Seridó (FAMUSE), no estande da Associação das Bordadeiras do Seridó (ABS), atualmente extinta. Em primeiro plano, está o pássaro. Está em um ramo com folhas, o que também suaviza a caatinga, uma vez que o pássaro 
parece não estar em uma terra árida. O bordado conta que a terra não é pobre, não para as bordadeiras.

Em Caicó, a natureza faz parte do repertório dos bordados, no entanto, como na análise da historiadora para as casas paulistas, trata-se de uma "natureza filtrada" e reelaborada, que surge fértil e suave (Carvalho, 2008). Assim, as artes manuais, que já sinalizavam uma forma de demonstrar o potencial econômico da família, encarnaram mais um papel a ser realizado no âmbito doméstico: aconchego e proteção. A casa era, segundo Carvalho, o "lugar de prazeres amenos, refúgio do homem cansado e preocupado" (idem, 2008: 63). Assim, os tecidos ornamentados simbolizavam uma boa administração doméstica, revelada pelo cuidado da casa e, por extensão, pelo zelo maternal.

Distante geograficamente de Caicó, mas próximo pela aridez da terra, o Irã tem uma relevante produção artesanal: os tapetes. Spooner (2008), ao analisar os tapetes iranianos, afirma que também nessa tradição artesanal (geralmente produzidos por mulheres), a natureza surge transfigurada:

\footnotetext{
Na tradição iraniana, em geral, há o desejo de intimidade com a natureza, ar fresco, luz, espaços abertos, mas uma aversão e uma apreensão diante da natureza em estado puro, sem qualquer proteção contra a ameaça das forças naturais. Em terras ermas, sem os confortos da vida sedentária, onde a natureza era incontrolável, viviam apenas os nômades. (Spooner, 2008: 268)
}

Essa perspectiva sobre a natureza e sobre a organização social do nomadismo é estigmatizada por imagens que assinalam que os "nômades simbolizavam a insegurança, a desordem social e a falta de controle político" (Spooner, 2008: 268), portanto, distintas do modelo civilizador. Diante disso, Spooner lembra que a maioria dos motivos singulares dos tapetes iranianos trazem representações sobre o jardim uma natureza organizada e civilizada pelo homem. Outros modelos trazem alguns objetos como jóias, lanternas e ladrilhos, representações da civilização como se fossem um jardim.

Essas análises podem ajudar a compreender a valorização da presença dos bordados nos lares e nas escolhas que priorizam as flores, os arabescos e a geometria dos pontos para a composição dos motivos. Perguntei, então, para algumas bordadeiras a razão de bordarem tantas flores. Iracema disse que se bordam flores "porque são lindas, copiar exige destreza, muita observação e conhecer a natureza"; Iasnaia disse 
que "é porque é tradicional, porque sempre foi feito assim", Rosário afirmou que "esta é a marca dos antepassados". As flores falam, segundo Iracema e Arlete, da herança portuguesa dos bordados de Caicó.

Carvalho (2008) faz a mesma pergunta para as casas paulistas ao perceber que os ornamentos inspirados na natureza compunham um repertório de motivos ornamentais, sendo que as flores mereciam uma "menção especial" nos artefatos produzidos pelas mulheres. A historiadora observa que se acreditava, no início do século XX, que o uso das flores podia incentivar, nas mulheres, o gosto pela comparação, pela combinação de cores, de formas, de aromas, e que simbolizava a presença feminina no lar. Bordar é cuidar da família. As flores trazem representações sobre a suavidade e a vida domesticada (amaciada e curada), e, em Caicó, talvez os bordados tenham conseguido amansar e civilizar o curral, a lida com o gado e o território de incertezas.

A percepção de uma natureza agressiva a ser enfrentada é entendida por muitos, até hoje, como uma marca do Seridó (Medeiros Neta, 2006). Mas a experiência com o bordado subverte essas imagens. As políticas e os discursos intervencionistas retomam o tema da carência da região para pensar possibilidades de superação, no entanto, os bordados, trazem outra leitura do lugar e da paisagem natural: leitura eminentemente feminina que apara as arestas, que cria pontes entre o público e o privado, que reinterpreta a natureza, produzindo outro ambiente.

Esta arte doméstica, feminina, tradicional, apresenta releituras da natureza, do contexto vividos pelas artesãs, bem como dos olhares únicos e individualizados acerca de suas vidas; que assim o fazem por meio da produção e do embelezamento dos tecidos. Ainda que a experiência estética e a prática artesanal se ordenem a partir de uma vivência pessoal, a cultura artesanal abrange os mais variados relacionamentos que se tangenciam no processo de produção, promovendo, a criação de vínculos em vários níveis, reunindo passado e presente em uma mesma peça e, assim, construindo uma forma de estar e de ver o mundo (Brito, 2011).

\section{Bordado como uma narrativa no corpo}

Bordados são parte do universo das mercadorias. Pertencem a um circuito econômico que atravessa séculos, tem valor de uso e troca; porém ultrapassam as regras restritas do fluxo econômico, uma vez que envolvem um processo cognitivo e cultural. 
Appadurai considera que certas mercadorias têm uso retórico e social, criado a partir de traços distintivos de registro. A criação e a feitura de tecidos artesanais, de rendas e de bordados podem ser consideradas parte deste grupo de objetos. Seguindo a lógica do autor, trata-se de objetos de acesso restrito, cuja aquisição é complexa; trazem consigo virtuosidade semiótica sendo regulamentados pela moda e têm um alto grau de associação entre consumo, corpo, pessoa e personalidade (Appadurai, 2008), seja ela de quem faz ou de quem consome.

Os bordados são artefatos que possuem, ainda, uma dimensão visual importante e estão presentes, de alguma forma, na vida cotidiana. Suas bordadeiras são usualmente anônimas e, ainda que seja uma experiência estética realizada em ambientes usualmente domésticos e com base em materiais que são entendidos como menores e com funções utilitárias demarcadas (se comparados à high art), bordar e consumir bordados tem como função social "diferenciar e/ou humanizar ambientes e pessoas" (Neira, 2011: 285).

Bordar é uma atividade que têm atravessado séculos revelando modelos de trabalho doméstico, ensinando perspectivas de gênero e atributos morais na arte do fazer criativo, algumas vezes, acompanhados de concepções religiosas - que se repercutem na manutenção da casa e de zelo pela família como consequência do lapidar de um modelo de caráter feminino ${ }^{11}$. Ao partirmos do pressuposto que a cultura se manifesta, dentre outras formas, nos artefatos, há nestes objetos um lócus de significação no mundo social (Bittencourt, 1996: 98); como a arte, trata-se de uma forma de representação, ligada à emoção estética, explicitamente construída, e que conduz a uma subjetividade (Severi, 2011).

Para as bordadeiras, em geral, os bordados também são mais do que o uso uma técnica de ornamentação de tecidos. Assim sendo, como expressão estética, inserida em uma rede produtiva, o bordado produz encantamento e reciprocidade, incorpora ações e representações por meio de seus agentes e pode ser concebido como um processo de comunicação, nos mais variados níveis (Lagrou, 2002). Bordados trazem em si narrativas sobre quem os produz, apresentam contextos de produção, de distribuição e de recepção das peças, envolvem relações sociais, criadas em torno da arte de bordar,

\footnotetext{
${ }^{11}$ É válido destacar a relação entre bordados e programas católicos de educação e de ensino religioso que fomentaram o ensino destas práticas artesanais. O projeto civilizador colonial, principalmente jesuítico, levava consigo o princípio de ocupar a mente, tornando-a útil e moralmente aprovada.
} 
considerando perspectivas historicamente engendradas, questões de gênero e distintas gerações envolvidas no ofício de bordadeira.

As bordadeiras articulam um conhecimento próprio sobre a arte de bordar. Esse conhecimento envolve fases, personagens, situações de ensino e de aprendizado, ligadas às distintas gerações das quais são parte, mobilizando um saber especializado e sofisticado. Diante da lógica estética dos bordados, há um elo interessante entre coisas e pessoas, com um olhar sui generis que humaniza o meio através das representações imagéticas. São artefatos que trazem perspectivas históricas, referências múltiplas e se apresentam (re)significados, seja por meio da elaboração técnica, seja pelos discursos tecidos sobre estes mesmos objetos por aqueles que o produzem e o consomem.

Quando nos aproximamos de uma prática, como o bordado, algumas frases são comuns de se ouvir, dentre elas que o "bordado é uma herança" "passada de mãe para filha". É de uma geração para a outra que se aprende: o quê e como fazer, o que ensinar, quando ensinar, como ensinar, o que não ensinar e os segredos a serem mantidos. Esse ensino e aprendizado do bordado, contudo, apresenta mais do que a transmissão de uma técnica, uma vez que traz consigo concepções sobre o que é ser boa bordadeira. E, ao mesmo tempo, apontam para uma preocupação corrente, na qual algumas crêem que o bordado é uma prática em extinção (visto o desinteresse das jovens por aprender a bordar).

A análise de Beatriz Góes Dantas sobre as rendeiras de Divina Pastora (Sergipe) inspira a investigação sobre o aspecto geracional que cerca a produção artesanal do bordado de Caicó. Assim como no caso das rendeiras, no bordado de Caicó, a noção de geração perpassa os mais variados discursos, abrangendo desde as técnicas - e seu ensino - até as formas de relacionamento estabelecidas em função do artesanato.

Durante a pesquisa, busquei considerar essas narrativas e tentei encontrar referências sobre o aspecto geracional, interpretando-a de modo literal. Algumas, como Iasnaia e Lucineide, aprenderam a bordar em suas casas, com a mãe. Ana ensinou duas filhas, assim como Helena também o está faz. Iracema, por sua vez, ensinou sua mãe, invertendo a relação "mãe/filha". Algumas das mulheres que bordam e que têm filhas, como Idelice, Iara, Ana Maria e Ivaneide, não quiseram ensinar o ofício para suas filhas. O único rapaz presente nesse trabalho aprendeu a bordar com as mulheres que ele empregava, na produção de redes bordadas. Maria, Edilma e Maria Helena aprenderam a bordar extinta ABS. 
Helena, por sua vez, contou-me que estava ensinando suas filhas a bordar, assim como aprendeu com sua mãe que, por sua vez, aprendeu com a avó. Nossa conversa ocorreu em 1997, por ocasião da abertura da Feira de Artesanato dos Municípios do Seridó - Famuse, a feira de artesanato mais importante da região e que acompanha os festejos de Sant'Ana. No evento de abertura da Famuse, a família de Helena estava bordando. Eram cinco mulheres, sentadas em uma grande mesa, com alguns trabalhos expostos, inclusive peças em processo de feitura, ainda junto aos bastidores e, no final da mesa, uma máquina Singer de pedal em que costuravam. Havia uma mesa comprida em frente ao palco do Centro de Exposições Ilha de Sant'Ana e, sentadas à mesa, Helena, uma de suas irmãs, sua mãe (que receberia uma comenda do CRACAS em reconhecimento pelo seu trabalho com o bordado) e suas duas filhas (uma com 9 e outra com 11 anos). Na máquina, ao final da mesa, mas ainda na mesma direção, outra irmã de Helena. A cena traduzia uma performance interessante do oficio de bordar que reafirmava o aspecto geracional e o aprendizado familiar. Helena parecia muito feliz e afirmava que o bordado era assim: "a mãe dela a ensinou e, agora, ela ensinava as suas filhas".

Assim que a mesa foi composta, Davina se aproximou e disse, com muita convicção: "Só assim o bordado daqui sobrevive. É assim que sempre se fez e se fará. Só quando a mãe ensina a filha é que se tem um bordado de verdade. A geração é o mais importante, não tem outro jeito". Todas concordaram.

Eu estava encantada com a filha mais nova de Helena. A menina é muito bonita, estava vestida com um vestido todo bordado que sua mãe havia feito e que contava a "Historinha do Sabiá". Ela estava empolgada em participar da feira e orgulhosa dos seus primeiros bordados (algo raro entre as meninas de Caicó, nos dias de hoje). A pequena bordava vagonite $^{12}$ (um ponto que não é muito popular em Caicó, mas é frequente vê-lo em revistas de artesanato, encontradas nas bancas de jornal em todo o país) e mostrava para as tias e avó o que estava fazendo.

Logo começamos a conversar, contei-lhe o que estava fazendo e ela me disse que gostava muito de bordar. No meio da conversa, perguntei se era difícil bordar e quem a estava ensinando, ao que ela respondeu: "é facinho, estou aprendendo na Igreja, pertinho de casa". Em um primeiro momento, estranhei o fato da mãe não ser a única

\footnotetext{
${ }^{12}$ Estilo popular de bordados, feitos em forma de alinhavos e de pontos contados pelos grupos de fios uniformes na trama do tecido. Usualmente com resultados geométricos, é realizado em cores de linhas contrastantes e com efeito degradê.
} 
responsável pelo treinamento da filha, depois entendi que se tratava de um movimento mais amplo. Para bordar é preciso saber mais do que a execução dos pontos do bordado, ou entender a lógica do repertório das composições, é preciso um aprendizado contínuo sobre o que é ser uma bordadeira, o que não se limita ao treinamento técnico.

No caso da menina, apesar do ensino dos pontos e da técnica do bordado ser realizado fora de sua casa, o aprendizado sobre o que é ser uma bordadeira se dá no lar, com sua mãe, observando o cotidiano, o ritmo do trabalho e a forma de agir das mulheres, em família. Mais do que técnicas, o que se ensina na família é ser bordadeira, como fora aprendido com as gerações que a antecederam. Ensinar a bordar é mais do que um processo de treinamento profissional, não se resumindo às aulas. Mais do que técnicas, a relação direta ensina formas de interpretar o ofício, indicando uma continuidade da própria vida.

Seguindo os passos de Benjamin (1988), é possível considerar a bordadeira como uma narradora e sua prática artesanal como uma narrativa. Bourdieu e Mammeri observam que o narrar e o ser artesão trata-se de um processo de construção do ser, por isso, uma "arte de viver" que se "aprende pela prática e que tem funções práticas" (Bourdieu e Mammeri, 2005: 64). A bordadeira, então, como parte do grupo dos artesãos, é considerada como uma mediadora.

O olhar de Lévi-Strauss para o grafismo kadiwéu pode ser inspirador para esta análise (Lévi-Strauss, 1989). Como lembra Severi (2011), o antropólogo aloca a experiência criativa da produção artística em um modelo de comunicação coletiva, uma vez que ele não acredita no "exercício criativo absoluto". A experiência criativa de um artesão, por exemplo, pode revelar uma habilidade de escolhas originais e de combinações que ocorrem no cerne de um repertório ideal rumo a uma "transposição qualitativa" das leituras sobre os rituais, os modelos culturais, as formas de composição social a natureza, e sobre como estes repertórios podem ser compartilhados coletivamente por meio do uso criativo dos materiais, das técnicas e dos conceitos disponíveis.

O conceito de geração e de experiência criativa podem se encontrar na interface deste processo ontológico que é a experiência estética ao tornar-se uma bordadeira. Se bordar é um exercício de acesso ao repertório coletivo, ensinar a bordar é, essencialmente, incorporar, por meio de técnicas e de aprendizado - motor e estético as formas possíveis e as possibilidades criativas das composições e das interpretações. 
Para isso, a gestualidades e as narrativas estão presentes durante todo o tecer da relação mestre-aprendiz.

Os processos de ensino do artesanato são baseados na transmissão oral e na imitação. $\mathrm{O}$ aprendizado passa pelo trabalho de uma profissional, de modo mimético: a aprendiz precisa estar atenta ao que se ensina, para, depois, repetir. Aprende-se a bordar, observando o trabalho de outra pessoa, sendo comum, portanto, a aprendiz prestar auxílio à bordadeira em diversas tarefas que, muitas vezes, transcendem às que são ligadas ao bordado, funcionando como moeda de troca - era comum, até há algum tempo, aprendizes trabalharem no serviço doméstico nas casas das bordadeiras, contando com a boa vontade da mestra para que lhe ensinasse a bordar. Além disso, como boa parte do bordado em Caicó é realizado na máquina de bordar - e este é um instrumento caro e nem todos a ele têm acesso - torna-se difícil treinar o bordado em casa. Este fato justifica a recorrente extensão do tempo de aprendizado, à medida que não se podem treinar os pontos sem as máquinas.

É comum a iniciação ao bordado ser feita a partir da execução de um "pano de amostra". O pano é composto pelos primeiros exercícios de ornamentação. Não há uma lógica de composição e nem se trata de um desenho específico, tal como o caderno de um aprendiz de gráfico, onde as letras constam apenas para o conhecimento dos estilos gráficos, ainda sem formar qualquer palavra ou, então, quando se aprende um instrumento e, antes de qualquer coisa, treinam-se as notas e a afinação. No limite, o pano de amostra é um exercício de afinação: ensina-se o modo de prender o bastidor, a paciência para seguir um ponto atrás do outro, a postura correta do corpo para evitar dores, as posições das mãos, a fim de obter a melhor execução do projeto, a distribuição das linhas no tecido e a escolha das cores.

O processo de iniciação no ofício artesanal é um tema importante. Ao analisar a produção das rendas (usualmente associadas aos bordados), Beatriz Góes Dantas (2005) observa temas importantes que cercam a perspectiva do ensino pelo ponto de vista da geração. A antropóloga está interessada em saber como é reproduzido socialmente o conhecimento sobre a manufatura das rendas, assim como refletir sobre as diferentes gerações de mulheres que vivem a experiência de aprendizado do ofício e, ainda, de que maneira os distintos sujeitos sociais criam e vivem situações de ensinar e aprender, repetindo técnicas e utilizando instrumentos seculares. 
$\mathrm{Na}$ investigação sobre a iniciação das rendeiras em Divina Pastora, Dantas (2005) destacou dois pólos privilegiados para o ensino do ofício. Em meio às redes de parentesco, prioritariamente os circuitos familiares - de mães, avós, tias, primas e cunhadas - e de vizinhança (incluindo as relações de amizade), é que as rendeiras são inseridas na prática artesanal. Nesses circuitos, a ideia corrente é que há um ensino que obedece à descendência: da avó para a mãe, da mãe para a filha.

No entanto, essas não são as únicas formas de aprendizado. Dantas (2005) destaca que a perspectiva geracional fala de um olhar do senso comum e de boa parte da bibliografia, o que não necessariamente corresponde à realidade das rendeiras de Divina Pastora (e, provavelmente, também não corresponde ao vivenciado em Caicó). Vê-se, por exemplo, que os dois primeiros polos (parentesco e vizinhança) caracterizam o ensino do ofício de fazer renda como algo geracional que logo são seguidos pelas rendeiras autodidatas (aquelas que foram observando, imitando ou, como dizem, "vendo e fazendo") e também por aquelas que aprenderam a bordar por vínculos institucionais, tais como escola ou associações. O que importa, segundo a autora, é que essa consideração acerca da hereditariedade valoriza a perspectiva de ensino por meio da oralidade e da informalidade das práticas artesanais, sendo que os processos de aprendizado artesanal seriam melhor compreendidos a partir dos contextos relacionais.

Voltando à realidade de Caicó - e considerando as falas sobre o aprendizado em casa, com a mãe, a performance da família de Helena e o movimento de aprendizado empreendido por sua filha -, é possível seguir a reflexão proposta por Dantas (2005) sobre geração e, a análise realizada por Mead (1995), para quem o conceito de geração pode ser entendido em vários níveis possíveis; expandindo a noção do senso comum, marcada pela descendência hereditária.

A filha de Helena aprende com a mãe, com a avó e com as tias. Aprende no cotidiano, na procura pelas opiniões e aprovação das mais velhas frente ao seu bordado e, principalmente, pela maneira com que as bordadeiras se relacionam com o bordado, com as demais bordadeiras e com o mercado. A menina aprende também com outras meninas da mesma idade, que fazem o mesmo curso na Igreja e que comunicam outros aprendizados, uma vez que elas também compartilham, em seus circuitos, formas de lidar com o bordado. Por fim, essas meninas podem, ainda, ensinar outras coisas que as mais velhas não sabiam e que são típicas de sua geração (provavelmente, apresentando 
outras composições para os bordados de sua mãe, uma vez que têm acesso a outras redes, inclusive, às redes virtuais).

Tive contato, algumas vezes, com esse processo de aprendizado. Em certas ocasiões, quando Iracema me explicava pacientemente a execução dos pontos, falava sobre o modo como havia formado as suas referências estéticas, descrevendo quem a havia ensinado a fazer determinado ponto, a melhor linha para bordar, as cores são mais apropriadas ou, então, porque fazia uma determinada composição e não outra. Explicoume os sentidos de corte do tecido, da resistência dos ornamentos, do tipo de risco mais adequado à peça e, com frequência, dizia-me para sentar à máquina para bordar porque eu já estava pronta, eu já sabia o que era o bordado, que era só começar. Conforme contava sobre o bordado, ensinava-me o que ela acreditava ser um bom bordado.

Apesar de não ter sentado à máquina, compartilho as referências de Iracema sobre essa prática, os movimentos que marcam o ensinamento do bordado, que mobilizam uma espécie de filiação. Assim, mais relevante do que "passar de mãe para filha" é saber que aquele que borda o faz como aprendeu, o que corresponde à forma pela qual a bordadeira que lhe ensinou bordava.

O "que (se) passa de mãe para filha" é mais do que o ensino das técnicas entre pessoas da mesma família, pois isso pode ser encontrado em cursos, livros, revistas ou em sites de busca, das referências que moldam tal filiação estética, a escolha de materiais, temas, destinos possíveis da peça, a divisão e organização do trabalho. Saber bordar, bordar bem ou mal, o estilo em que se borda, ser excelente ou produtivo, no traço, depende do grau de aproximação e da afinidade com o mestre - seja ele um parente consanguíneo ou não. Além disso, a aprendiz não aprende somente a produzir o objeto, mas a relacionar-se com ele por meio do "domínio de um quadro de referências alicerçadas sobre tradições e sobre eventos que marcam a história dos grupos" (Dantas, 1995: 225), cuja transmissão de saber implica em uma mudança nas formas de vida, de um novo modo de ser.

\section{Considerações Finais}

A produção artesanal envolve a domesticação do corpo e a sensibilização estética. Soma-se a isso o fato de que mais do que aptidões e heranças, "as construções sociais em torno do corpo correspondem à diferença de atitudes dos corpos”, que, não por acaso 
são "socialmente construídas" (Mauss, 2003 [1931]: 408 e 409). Esta arte doméstica, feminina, tradicional, apresenta releituras da natureza, do contexto vividos pelas artesãs, bem como dos olhares únicos e individualizados acerca de suas vidas; que assim o fazem por meio da produção e do embelezamento dos tecidos.

Os objetos artesanais de linhas e agulhas são acompanhados por uma ética da paciência que se manifesta em uma estética impecável, em torno de uma sociabilidade e tempos femininos (Denis, 2005); ora, as práticas artesanais engendram uma gama múltipla de ações, desenvolvidas por processos de aprendizado, domínio de técnicas e de repertórios estéticos que as compõem. Incorporam, ainda, escolhas - que também são pessoais - e modos de lidar com um conhecimento que se refaz criativamente, pelas gerações (Gordon, 2004).

Apenas para destacar uma destas práticas, aprender a bordar, por exemplo, apresenta uma relação contínua com a disciplina do corpo em prol da excelência do produto, estabelecida por um longo treino que vai além do ensino de bordar em si, moldando a forma de ser de uma bordadeira e criando uma cultura do bordado. Ainda que a experiência estética e a prática artesanal se ordenem a partir de uma vivência pessoal, a cultura artesanal abrange os mais variados relacionamentos que se tangenciam no processo de produção, promovendo, a criação de vínculos em vários níveis, reunindo passado e presente em uma mesma peça e, assim, construindo uma forma de estar e de ver o mundo (Brito, 2011).

\section{Referências}

APPADURAI, A. (ed.). A vida social das coisas. As mercadorias sob uma perspectiva cultural. Niterói: Editora da UFF, 2008

BRITO, Thaís F. S. Bordados e bordadeiras. Um estudo sobre a produção artesanal de bordados em Caicó/RN, 2011. Tese (Doutorado em Antropologia Social). São Paulo: Universidade de São Paulo, São Paulo, 2011.

CÂMARA CASCUDO, Luís. História do Rio Grande do Norte. Rio de Janeiro: MEC, 1955. Rede de dormir. Uma pesquisa etnográfica. 2. ed. São Paulo: 2003.

CAPISTRANO DE ABREU, João. Capítulos de História Colonial. [1930]. Ministério da Cultura/ Fundação Biblioteca Nacional/ Departamento Nacional do Livro. Disponível em: <http://www.scribd.com/doc/6591474/Capitulosdehistoriacolonial-Capistrano-de-Abreu>. Acesso em: 7 ago. 2009. 
CAVIGNAC, J. A. Vozes da Tradição: reflexões preliminares sobre o tratamento do texto narrativo em Antropologia. Horizontes Antropológicos. Porto Alegre, v.12, pp. 245-265. 1999.

CARVALHO, Vânia C. de. Gênero e artefato. O sistema doméstico na perspectiva da cultura material: São Paulo, 1890-1920. São Paulo: Edusp/FAPESP, 2008.

DANTAS, Beatriz Góis e Antonio Arantes. Renda de Divina Pastora. Rio de Janeiro: Funarte, CNFCP. (Sala do Artista Popular, 92). 2001.

DANTAS, Beatriz Góis. Tu me ensina a fazer renda: gerações e processos de aprendizagem de ofícios tradicionais. In: CUNHA, M. C. (org.) Revista do Patrimônio Histórico e Artístico Nacional, Brasília, n. 32, 2005.

DENIS, Maria N. Les brodeuses d'autrefois. In: Gatineau, Barbara; Tourscher, Alexadre (org). Broder sans compter. L'Art de la broderie en Alsace su 16e au 20e siècle. Strasbourg: Les Musées de Strasbourg, 2005.

DURAND, Jean-Yves. Bordar: masculino, feminino. In: Reactivar saberes, reforçar equilíbrios locais. Vila Verde: Aliança Artesanal, 2006. Disponível em: <http://hdl.handle.net/1822/5480.pdf> Acesso em: 17 fev. 2008.

FALCI, Miridan K. Mulheres do sertão nordestino. In: DEL PRIORI, Mary. História das mulheres no Brasil. 3. ed. São Paulo: Contexto/UNESP, p. 241-277. 2000.

GOMES, Regina. Quer casar? Aprenda a bordar ... e depois, por que não comercializar? Revista Museu do Seridó. Caicó: Museu do Seridó/UFRN/PROEX/CERES, 2004.

GONÇALVES, José Reginaldo G. S.. Ressonância, imaterialidade e subjetividade. As culturas como patrimônio. Horizontes Antropológicos. Porto Alegre, ano 11, n. 13, pp. 15-35, jan/jun., 2005.

GORDON, Sarah A.. "Boundless Possibilities": Home Sewing and the Meanings of Women's Domestic Work in the United States, 1890-1930. Journal of Women's History, v. 16, n. 2, pp. 68-91, 2004.

GÜINER, Eduardo. De íconos y contorsiones. Hacia una politica "warburguiana" en la antropología del arte. Disponível em <http://www.revoluciones.org/v.1/sites/default/files/de_iconos_y_contorciones.pdf> Acesso em 23 set. 2013.

HERZFELD, Michael. Cultural intimacy. Social poetics in the nation-state. New York/London: Routledge, 1997.

KOPYTOFF, Igor. A biografia cultural das coisas: a mercantilização como processo. In: Appadurai, A. (ed.). A vida social das coisas. As mercadorias sob uma perspectiva cultural. Niterói: Editora da UFF. pp. 89-124. 2008.

LAGROU, Elsje M. Poder criativo e domesticação produtiva na estética Piaroa e Kaxinawá. Revista Cadernos de Campo, São Paulo, n.5/6, p. 47-61, 1996.

O que nos diz a arte kaxinawa sobre a relação entre identidade e alteridade. Mana 8, vol, p. 29-61, 2002.

LÉVI-STRAUSS, Claude. O pensamento selvagem. São Paulo: Papirus editora, 1989. 
LORENZI, H. Árvores brasileiras: manual de identificação e cultivo de plantas arbóreas do Brasil. São Paulo: Nova Odessa, v. 2, 2002.

MACEDO, Helder A. M. Cultura, tradição e patrimônio imaterial. Mneme. Revista de Humanidades. Caicó (RN), v. 7. n. 18, p. 9-29, 2005.

- Contribuição ao estudo da Casa-Forte do Cuó, Caicó-RN. Dossiê Arqueologias Brasileiras. Mneme. Revista de Humanidades. Caicó (RN), v. 6. n. 13, 2004/2005. Disponível em: <http://www.cerescaico.ufrn.br/mneme/pdf/mneme13/133.pdf> Acesso em: 5 jan. 2009.

MACEDO, Helder. Sertões do Seridó: Estudos de História Colonial. Carnaúba dos Dantas: Bookess Editora, 2012.

MACEDO, Muirakitan K. A penúltima versão do Seridó: Espaço e história no regionalismo seridoense. 1998. Dissertação (Mestrado em Ciências Sociais) - Universidade Federal do Rio Grande do Norte, Natal, 1998.

Tudo o que brilha é ouro-branco - as estratégias das elites algodoeira-pecuarísticas para a construção discursiva do Seridó norte rio-grandense. In: Mneme - Revista de Humanidades, Caicó (RN), v.5, n.13, 2004/2005.

MAUSS, Marcel. Sociologia e antropologia. São Paulo: Cosac \& Naif, 2003.

MEAD, Margaret. Adolescencia y cultura en Samoa. Barcelona: Paidós, 1995.

MEDEIROS, José Augusto B. de. Seridó. Brasília: Centro Gráfico do Senado Federal, 1980.

MEDEIROS Filho, Olavo. Notas para a história do Rio Grande do Norte. João Pessoa: Unipe Editora, 2001.

MEDEIROS NETA, O. M. de . Escrita (de)marca espaços: A historiografia e a produção do seridó potiguar. Revista História Hoje, São Paulo, v. 4, p. 1-23, 2006.

MORAIS, Ione R. D. Seridó norte-rio-grandense: uma geografia da resistência. Caicó: Ed. do autor, 2005.

NEIRA, Luiz García. Discursos distintivos a partir da cultura material têxtil no Brasil (18471910). Revista Estudos Históricos. Rio de Janeiro, v. 24, pp. 284-304, jul/dez, 2011.

SENAI. A história da indústria têxtil paulista. São Paulo: Artemeios, 2007.

SEVERI, Carlo. A ideia, a série e a forma: desafios da imagem no pensamento de Claude LéviStrauss. Revista Sociologia \& Antropologia. V. 01.02, pp. 53-75, 2011.

VIEIRA, Alberto. Bordado da Madeira. Funchal: Bordal, 2006.

Recebido em: 07/09/2013

Aprovado em: 15/10/2013 